\title{
Hydrological Characterization of Water Resources Used for Sugarcane Production in the Sugar Complexes of Ferkessedougou (North of Côte d'Ivoire)
}

\author{
Affoué Berthe Yao1*, Sampah Georges Eblin1, Gla Blaise Ouedé1, Kouakou Lazare Kouassi1, \\ Do Ange Désiré Soro', Arona Diedhiou ${ }^{2}$, Bi Crépin Péné ${ }^{3}$ \\ ${ }^{1}$ Laboratory of Environmental Sciences and Technologies, UFR Environment, Jean Lorougnon Guédé University, Daloa, Côte \\ d'Ivoire \\ ${ }^{2}$ Laboratory NEXUS “Climate, Water, Agriculture, Energy Nexus and Climate Services” Research and Development Institute, Felix \\ Houphouët Boigny University, Abidjan, Côte d'Ivoire \\ ${ }^{3}$ Research and Development Department, SUCAF-CI, Ferkessedougou, Côte d'Ivoire \\ Email: *y_berth@yahoo.fr
}

How to cite this paper: Yao, A. B., Eblin, S. G., Ouedé, G. B., Kouassi, K. L., Soro, D. A. D., Diedhiou, A., \& Péné, B. C. (2021). Hydrological Characterization of Water Resources Used for Sugarcane Production in the Sugar Complexes of Ferkessedougou (North of Côte d'Ivoire). Journal of Geoscience and Environment Protection, 9, 1-15. https://doi.org/10.4236/gep.2021.912001

Received: October 5, 2021

Accepted: November 30, 2021

Published: December 3, 2021

Copyright $\odot 2021$ by author(s) and Scientific Research Publishing Inc. This work is licensed under the Creative Commons Attribution International License (CC BY 4.0).

http://creativecommons.org/licenses/by/4.0/ (c) (i) Open Access

\begin{abstract}
Water resources, although renewable, are limited and threatened by climate change and anthropic activities. Assessment and forecasting of these resources can provide valuable information for water resource planners. This study aims to quantify the surface water resources used for sugarcane production in sugar complexes of Ferkessedougou. This is based on the morphological characterization of the river Morrison and Lopkoho dams and on extreme daily flow probability of occurrence estimation using frequency analysis method. The bathymetric survey showed that the Morrison Dam impoundment had a maximum depth of $11.98 \mathrm{~m}$; a water capacity of $11,656,735.5 \mathrm{~m}^{3}$. For the Lokpoho dam, the reservoir had a maximum depth of $8.82 \mathrm{~m}$, which corresponds to a water volume of $4,354,531.5 \mathrm{~m}^{3}$. Nevertheless, the water capacity of these reservoirs is greatly reduced by a large volume of sediment estimated at $1,013,058.96 \mathrm{~m}^{3}$ for Morrison and 599,740 $\mathrm{m}^{3}$ for Lokpoho. Statistical analysis of maximum daily flows shows that flows between 73.9 and $100 \mathrm{~m}^{3} / \mathrm{s}$ have the potential to occur every five years at the Route Korhogo Badikaha hydrometric station. The recurrence of the decennial $\left(298 \mathrm{~m}^{3}\right)$ and quinquenal $(248$ $\mathrm{m}^{3}$ ) flows shows the importance of the flood flows of the Bandama River. It also shows that the low water levels of the Bandama are very pronounced. The minimum flow that SUCAF-CI water managers should expect every five years is $1.36 \mathrm{~m}^{3} / \mathrm{s}$ and the ten-year low flow is $2.10 \mathrm{~m}^{3} / \mathrm{s}$. These results are indicators of water scarcity risks and could guide decision making in the Fer-
\end{abstract}


kessedougou sugar complexes.

\section{Keywords}

Bathymetric Survey, Flow Quantile, Return Period, Sugar Complexes, Côte d'Ivoire

\section{Introduction}

The dwindling of water resources poses a threat potentially important to the environment and economic activities (UNESCO, 2020). Among the main factors responsible for this situation are natural uncertainties observed in the climates, as well as the anthropic activities of a growing population (IPCC, 2014). Indeed, successive periods of drought since the 1970s caused waves of famine in West Africa due to crop loss and livestock decimation (Kouassi et al., 2017). Like the countries of West Africa, these impacts of climate changes have been strongly felt in Côte d'Ivoire due to the fact that its economy is essentially based on rain-fed agriculture and its strong dependence on rivers flows used for agricultural and industrial production and for water supply.

This is the case of the Sucrerie d'Afrique-Côte d'Ivoire (SUCAF-CI), an agroindustrial enterprise located in the departments of Ferkessedougou and Tafire, in the northeast of Côte d'Ivoire. This company exploits water of the Bandama River for sugarcane irrigation, sugarcane manufacturing and domestic needs through two water reservoirs (Morrison and Lokpoho) that were built to support the water supply of the sugar cane perimeters of Ferkessedougou. In recent years, managers of sugar estates have experienced enormous difficulties in meeting water needs due to decreasing flows of the Bandama River and the drying up of water reservoirs (Pene et al., 1997; Pene et al., 2001). This rapid drying up of reservoirs and silt deposits observed in the bottom of the reservoirs show signs of siltation and thus a reduction of the capacity of the reservoirs. Indeed, siltation and eutrophication of reservoirs cause flooding, significant changes in physicochemical parameters and quick development of aquatic plants. Despite the dangers inherent in the lakes filling over time (Ryding \& Rast, 1994), no sedimentological and morphological studies have been undertaken on the lakes of Ferkessédougou sugar complex dams. The work carried out by the CCC UE/CI (2013) was limited to an estimate of the volume of water in reservoirs without really characterizing the bottom of these lakes. In addition, the increase of the frequency of extreme events such as droughts, floods and very intense rainfall, mentioned by the GIEC (2012), highlights the need to make a frequency analysis of flood and low water flows in order to provide decision support in the research processes of strategies to fight hydro-climatic risks. Knowing that water scarcity is a factor reducing sugarcane productivity, this study is conducted to evaluate the current water availability of the reservoirs and to estimate the quantiles of extreme rainfall and flow and their probability of occurrence in order to consti- 
tute a decision support tool aiming at allowing SUCAF-CI to dispose of the water resource in a sustainable way. The study is based on the morphological characterization of water reservoirs and the frequency analysis of flood and low water flows of the Bandama River at the Route Korhogo Badikaha hydrometric station.

\section{Study Area}

The Upper Bandama watershed at the Korhogo-Badikaha road station is located between longitudes $5^{\circ} 00^{\prime}$ and $6^{\circ} 20^{\prime}$ West and latitudes $9^{\circ} 00^{\prime}$ and $10^{\circ} 20^{\prime}$ North (Figure 1). It covers the square degrees of the Poro, Tchologo and part of the Bagoue regions with an estimated area of $9850 \mathrm{~km}^{2}$ and represents about $10 \%$ of the entire Bandama River watershed.

The study area is under the influence of the transitional tropical regime characterized by two major seasons (Soro et al., 2013). A long rainy season from April to October, with average monthly rainfall ranging from 129.3 to $250.4 \mathrm{~mm}$ and a long dry season from November to March with average rainfall ranging from 1.9 to $82.5 \mathrm{~mm}$. Average monthly temperatures range from $25^{\circ} \mathrm{C}$ in August to $29^{\circ} \mathrm{C}$ in $\mathrm{March}$.

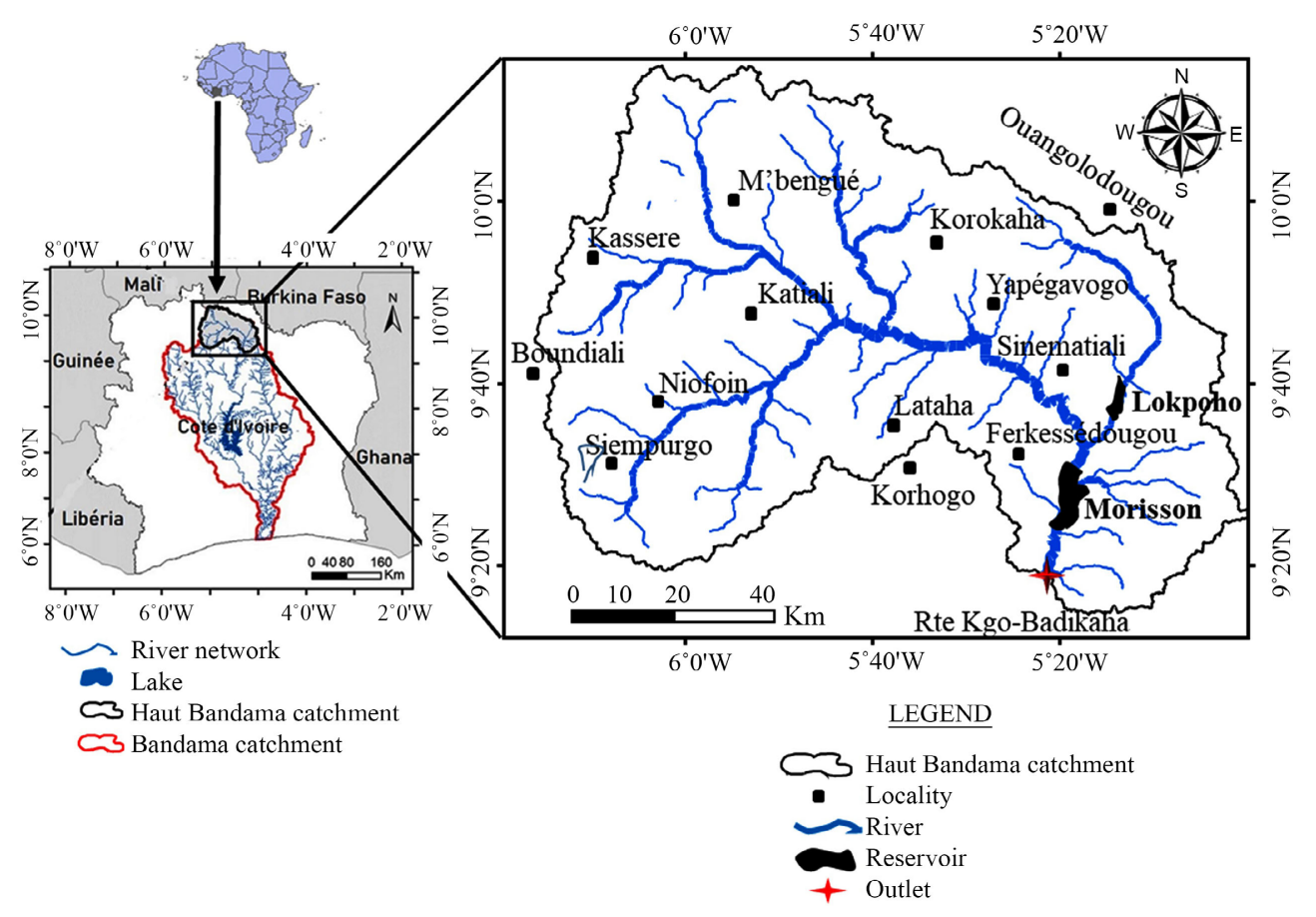

Figure 1. Location of the upper Bandama watershed.

\section{Materiel and Methods}

\subsection{Materiel}

The material is composed of data collected from national agencies and data measured in field. The data collected are the hydrometric data. Hydrometric data include flows data of the Bandama River at the Korhogo-Badikaha road sta- 
tion from 1975 to 2000; with a reconstruction of the missing data by rainfall-flow modeling using the GR4J model (Yao et al., 2012). This treatment required rainfall data recorded at the stations of Boundiali, M'Bengue, Korhogo and Ouangolo to calculate the average rainfall in the Upper Bandama watershed. These rainfall data come from the Society for the Operation and Development of Airports, Aeronautics and Meteorology (SODEXAM)). Data measured in field concern bathymetric surveys realised on Morrison and Lokpoho dams in 2013 by SUCAF-CI and the 20 and 21st February 2020 in the context of a project named "Climate services for sustainable sugarcane production and use in Africa" (CLIMSUCAF).

\subsection{Methods}

\subsubsection{Assessment of Water Availability in Reservoirs}

\section{Morphological characterization of the Morrison and Lokpoho reservoirs}

The morphology of the bottom of the Morrison and Lopkoho dams (Figure 2) was studied using bathymetric surveys. These surveys were carried out using a LOWRANCE Elite $9 \mathrm{Ti}$ echosounder; which is a device for measuring the depth of the sea bed or lake. The depth is deduced from the measurement of the travel time of an acoustic signal reflected by the bottom.

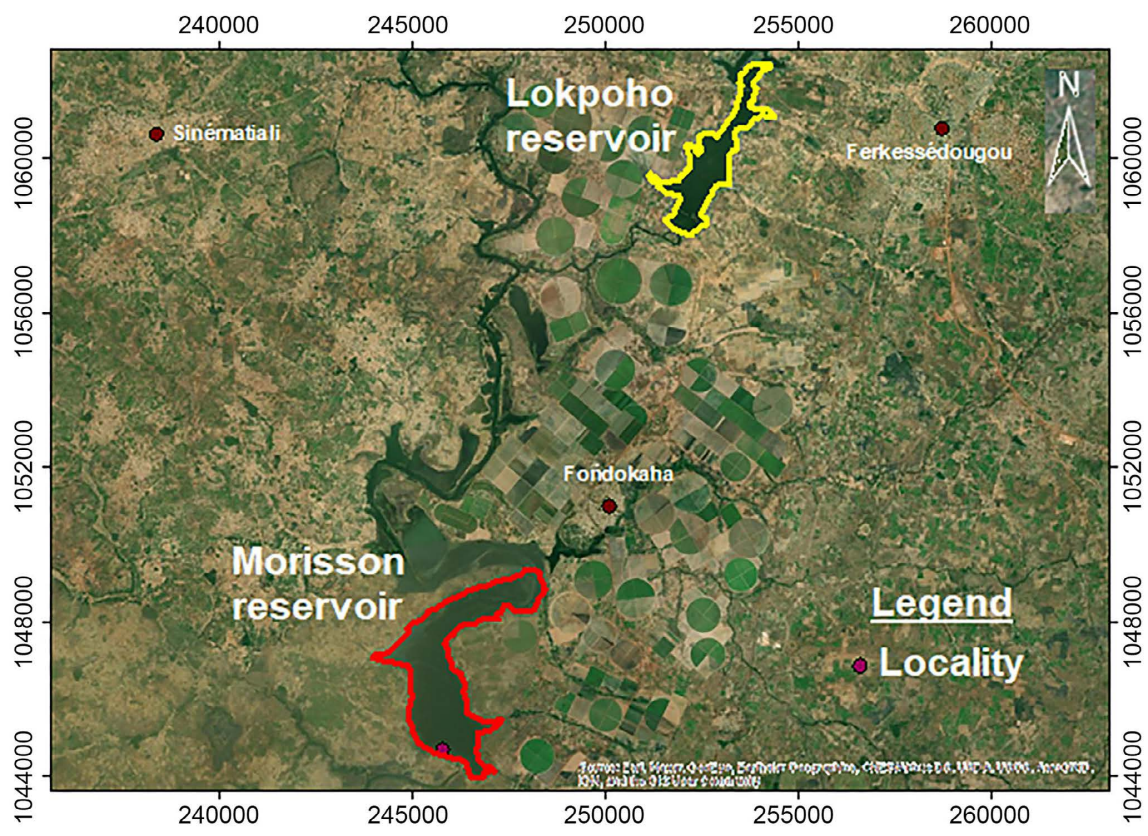

Figure 2. Overview of the bathymetric survey area (Google Earth, 2020).

The soundings were taken at a frequency of $455 \mathrm{kHz}$, to avoid that transmitted signals not to penetrate the silt (Kouassi et al., 2007). The depths obtained thus represent the distance between the position of the echo sounder transducer and the water-sediment interface. Water travel was conducted using a speedboat in both the longitudinal and transverse directions of the stream. These surveys were carried out over a length of approximately $3855 \mathrm{~m}$ for the Morrison Dam 
and $3815 \mathrm{~m}$ for the Lopkoho Dam. The interpolation method used was IDW (Inverse Distance Weighting) with an X and Y space step of $150 \mathrm{~m}$. It is a local deterministic interpolation technique that calculates the value of a point by averaging the values of the points located in the vicinity weighted by the inverse of the distance to the calculated point: the closer the points are, the greater the weighting assigned (Drouin \& Saint-Laurent, 2010).

\section{Establishment of height-volume and height-surface curves}

These impoundment contours give the different water volumes and areas for each impoundment contour (Nshimirimana, 2010). The partial volume $V_{i}$ between two successive contours is given by (1):

$$
V_{i}=\frac{\left(S_{i-1}+S_{i}\right) \times H}{2}
$$

$V_{i}$ : Volume of water between the contours $i-1$ and $i$;

$H$ : Height difference between the two contours $i-1$ and $i$, i.e. $H_{i}-H_{i-1}$;

$S_{i}$ : Surface of the water body corresponding to the curve $i\left(H_{i}\right)$;

$S_{i-1}$ : Surface of the water level corresponding to the curve $i-1\left(H_{i-1}\right)$

Thus, by applying these relationships for each height of the water body, the area of the water body is determined as a function of its height (Nshimirimana, 2010). In our study, these calculations were performed using COVADIS software. COVADIS is a software using the graphic interface of Autocad with in the background a calculation process using the usual topographic formulas. It proceeds by modelling the terrain given to it by linear interpolation.

Using the Height-Volume curve of the reservoir $(H=f(V))$, the Height-Surface curve $(H=f(S))$ was constructed.

\section{Volume and rate of sediment in the two dams}

The 2013 and 2020 bathymetric surveys provided sediments volumes. Thus, the difference between these volumes provides the current sediment volume in the reservoir in 2020. Then the rate $(\tau)$ of deposited sediment is calculated by $(2)$ (Kouassi, 2007):

$$
\tau=\left(\frac{B_{2020}}{B_{2013}}\right)^{\frac{1}{n}}-1
$$

With:

$\tau$ : Sediment rate (\%)

$B$ : Volume of sediment $\left(\mathrm{m}^{3}\right)$

$n$ : Year difference between 2013 and 2020

\subsubsection{Determination of the Probability of Occurrence of Extreme Flows}

This study is based on frequency analysis, which consists in determining the probabilities of occurrence and the return periods (forecast). The main objective of this statistical method is to use measurements of past events to estimate future probabilities of occurrence. The frequency analysis is used, in particular, to estimate the magnitude of the temporal event $x T$ to which is associated a return 
period $x T$ (quantile of return period $T$ or of probability at exceedance $T=1 / T$ (Bobée, 1999)). The estimate of quantile $x T$ value is obtained by fitting a probability law $F(x, \theta)$ to a sample of $n$ observations, $x=\left\{x_{1}, \cdots, x_{n}\right\}$ where $\theta$ represent a vector of parameters associated at the probability distribution $F$. The different steps on frequency analysis are as follows:

\section{Sampling}

The sampling of extreme flows concerned the flood (QMAXAN) and low water flows (QMIN) recorded at the hydrometric station Route Korhogo-Badikaha from January to December over the period 1975-2000.

\section{$>$ Choice of models}

The choice of the frequency model was made on the basis of graphical comparison and numerical comparison criteria (Kouassi et al., 2019). The graphical method allows one to graphically visualize the goodness of fit of a given law to a sample of data. The best probabilistic models are those whose curve passes through the maximum number of observations and whose Confidence Interval (CI) encompasses the maximum number of observations. This visual acuity-dependent graphical comparison method does not allow for the selection of the appropriate model for fitting the variables under study. Thus, in order to minimize the risk of error in the choice of the best fitting model, a second selection method based on the numerical comparison criteria of the laws must be used. Within the framework of this study, the choice of the frequency model was made by means of two approaches which are the graphic approach and that of the comparison criteria (AIC and BIC). This choice was made among four (04) frequency models (statistical laws) for flood flow series. These are: the general law of extreme values (GEV), the Gumbel law (EV1), the Weibull law (W) and the Lognormal law (LN). For the low-flow sample (minimum flows), the laws competed for are the Exponential law and the Gamma law because the fit of the other laws was negative (Catalogne, 2012). The maximum likelihood method was used to estimate the parameters of these laws. The application of these laws allows us to assess which one best fits a time series of rainfall and discharge. The ideal distribution is chosen using graphical and numerical criteria. For each sample, the test of independence, stationarity and homogeneity were previously analyzed using HYFRAN software. The HYFRAN-PLUS software allows the fitting of a large number of statistical distributions to a set of data that verify the assumptions of independence, homogeneity and stationarity (see DAS publications). It is designed to clearly present the steps involved in fitting a statistical distribution to a random sample. These steps can be found in Soro (2011).

\section{Comparison criteria}

The aim of these criteria is to find a compromise between a sufficient parameterization to fit a probability distribution to the observations and the least complex parameterization possible. To be able to compare probabilistic models by comparison criteria, we set equal a priori probabilities for all distributions. Then, we specify a return period $(\mathrm{T})$. Thus, the a posteriori probability is calculated from the a priori probability (Soro, 2011). The Akaike Information Crite- 
rion (AIC) (3) and the Bayesian Information Criterion (BIC) (4) are also calculated. The best probabilistic model is the one with low AIC and BIC values and the highest posterior probability (Soro, 2011). The BIC and AIC criteria are calculated as follows:

Akaike Information Criterion (AIC)

$$
\mathrm{AIC}=2 \log (l)+2 k \log (n)
$$

With 1 : likelihood; $k$ : number of parameters; $n$ : sample size

Bayesian information criterion (BIC)

$$
\mathrm{BIC}=-2 \log (l)+2 k
$$

With 1 : likelihood; $k$ : number of parameters

\section{o Model validation test}

Once the fitting model is chosen, it must be subjected to a series of tests to verify its fit to the chosen sample. In this study, the chi-square test $\left(\chi^{2}\right)$ was used.

The HYFRAN (Hydrological Frequency Analysis) software developed by INRS-EAU of Canada was used to implement the frequency analysis.

\section{Results}

\subsection{Water Availability of Reservoirs}

\subsubsection{Analyze of Morphology of the Reservoirs}

Figure 3 and Figure 4 show the bathymetric maps of the Morrison and Lokpoho impoundment. These maps were made using bathymetric surveys conducted in February 2020. For the Morrison reservoir (Figure 3), the $292.23 \mathrm{~m}$ water level was used as the reference level. The maximum depth sounded is $11.98 \mathrm{~m}$ and the area of the bathymetric survey is 472.92 hectares as of 20/02/2020. The bottom of the reservoir is characterized by a morphology disturbed by abrupt slope variations in the project area. These slopes reach $24^{\circ}$ in places.

For the Lokpoho impoundment (Figure 4), the bottom is slightly less rugged. On this bathymetric map, there is a main north-south flow channel leading to the water intake. Depths vary gradually from place to place from upstream to the dike. The depths are less important and reach $8.82 \mathrm{~m}$. The $296.97 \mathrm{~m}$ water level was chosen as the reference level and the area of the bathymetric survey is 312.93 hectares as of $21 / 02 / 2020$. The bottom of the reservoir is also characterized by a morphology disturbed by abrupt slope variations in the project area. These slopes reach $80^{\circ}$ in places.

\subsubsection{Current Capacity of the Reservoirs}

Figure 5 shows respectively the evolution of the volume of water and the average surface area of the reservoirs as a function of water depths. These curves show a logarithmic curve with a height of $292.23 \mathrm{~m}$ and $296.97 \mathrm{~m}$ respectively for Morrison and Lokpoho. For the Morrison reservoir, this water level corresponds to an area of $32.000 \mathrm{~m}^{2}$ (Figure $5(\mathrm{a})$ ) and a volume of $11,656,735.5 \mathrm{~m}^{3}$ on 20/02/2020 (Figure 5(b)). 


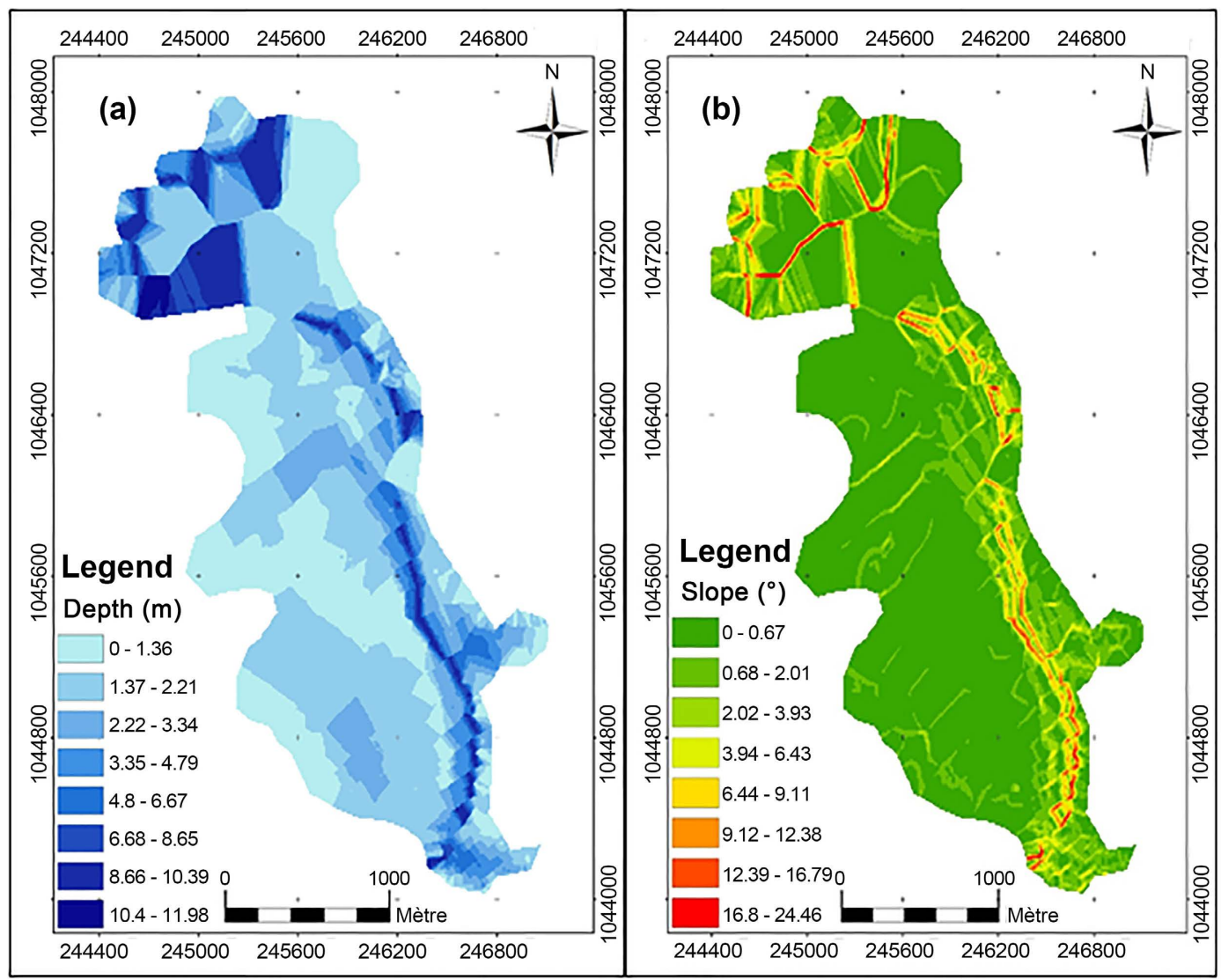

Figure 3. Bathymetric map of Morrison Reservoir: depths (a), slopes (b).
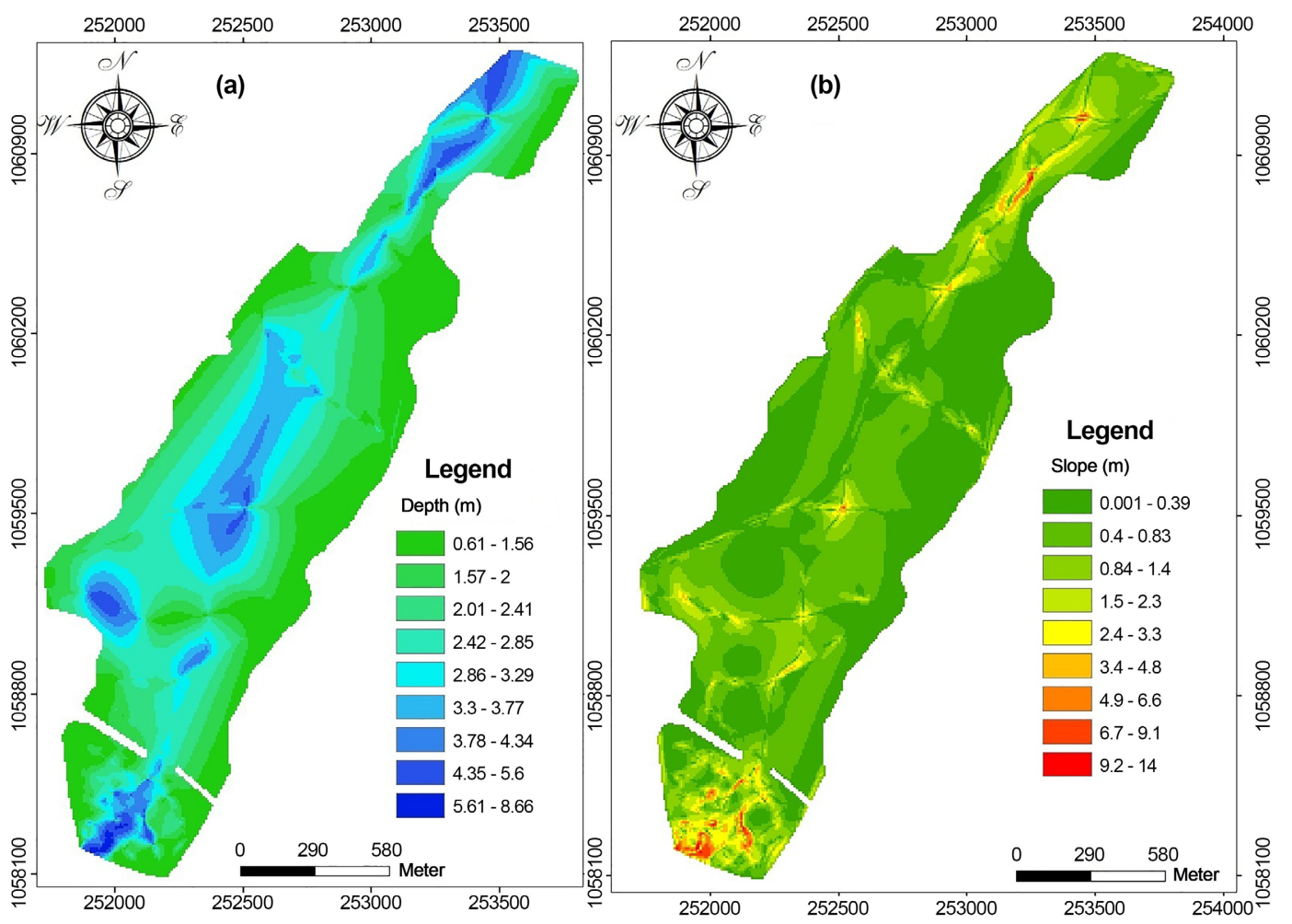

Figure 4. Bathymetric map of the Lokpoho reservoir: depths (a), slopes (b). 


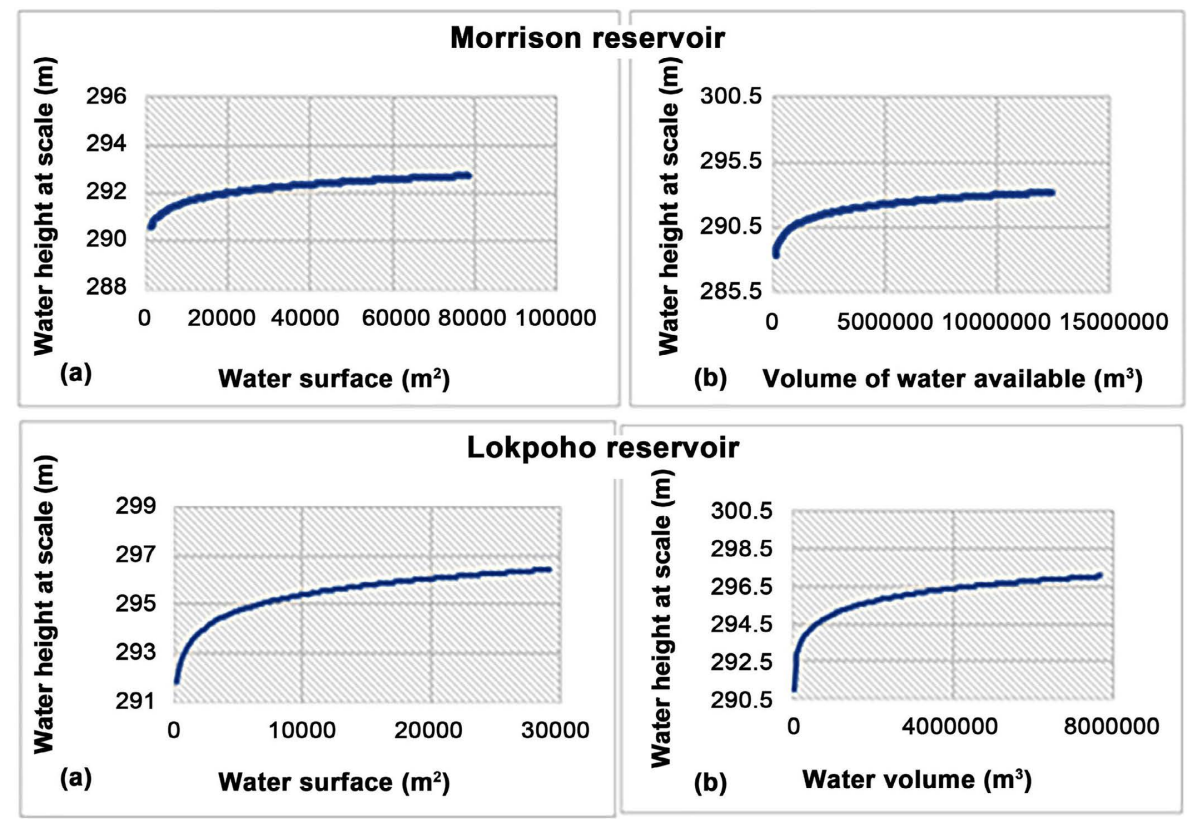

Figure 5. Reservoir capacity: (a) Height-surface curve; (b) height-water volume curve.

And for the Lokpoho reservoir, this water level corresponds to a surface of $27,000 \mathrm{~m}^{2}$ and a volume of $4,354,531.5 \mathrm{~m}^{3}$ on $21 / 12 / 2020$.

\subsubsection{Analysis of the Sediment Content of the Reservoirs}

The sediment levels in the two impoundments between 2013 and 2020 are recorded in Table 1. Analysis of the results shows that the sediment rate in Morrison impoundment is lower than that in Lokpoho. Indeed, for the Morrison reservoir, sediments volume varies from $875,900 \mathrm{~m}^{3}$ in 2013 to $1,013,058.96 \mathrm{~m}^{3}$ in 2020 or a sedimentation rate of $2.1 \%$. For Lopkoho reservoir, the results of sediments volume in 2013 is $508,000 \mathrm{~m}^{3}$ and in 2020 , this volume is estimated at $599,740,543.3 \mathrm{~m}^{3}$ or a sedimentation rate of $2.4 \%$.

Table 1. Sediment levels in the two reservoirs.

\begin{tabular}{cccc}
\hline \multirow{2}{*}{ DAMS } & \multicolumn{2}{c}{ Volume of sediment $\left(\mathrm{m}^{3}\right)$} & \multirow{2}{*}{ Rates (\%) } \\
\cline { 2 - 3 } & 2013 & 2020 & \\
\hline Morrison & 875,900 & $1,013,058.96$ & 2.1 \\
Lokpoho & 508,000 & $599,740,543.3$ & 2.4 \\
\hline
\end{tabular}

\subsection{Probability of Occurrence of Extreme Flows}

\subsubsection{Adjustment of Maximums Flows}

The maximum daily flows recorded at the Korhogo-Badikaha station follow the GEV and Gumbel laws (Figure 6). Indeed, the observations are all within the Confidence Interval and, moreover, remarkably close to the curve representing the probabilistic models mentioned above. These results are confirmed by those in Table 2, which present the ranking of the probability laws fitted to the annual maximum flow series of the Korhogo-Badikaha road station. 
Bandama at the Korhogo-Badikaha station

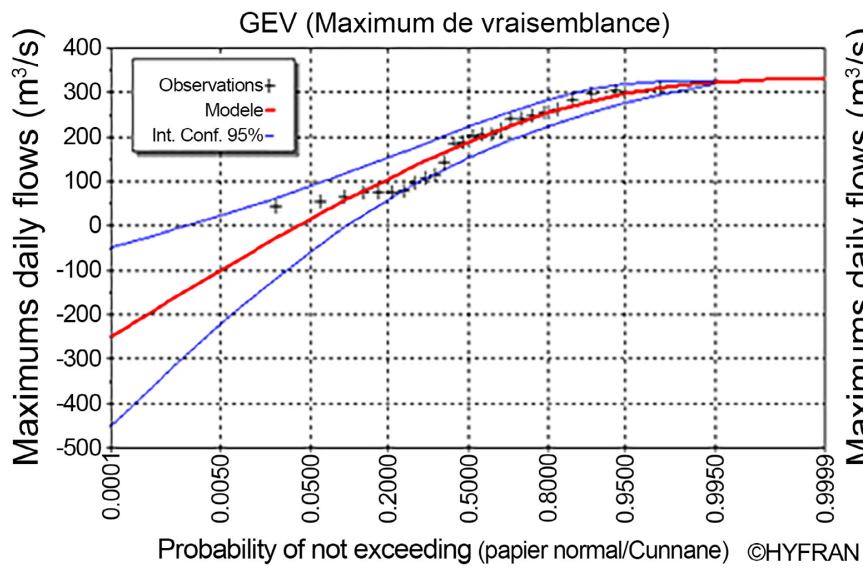

Bandama at the Korhogo-Badikaha station

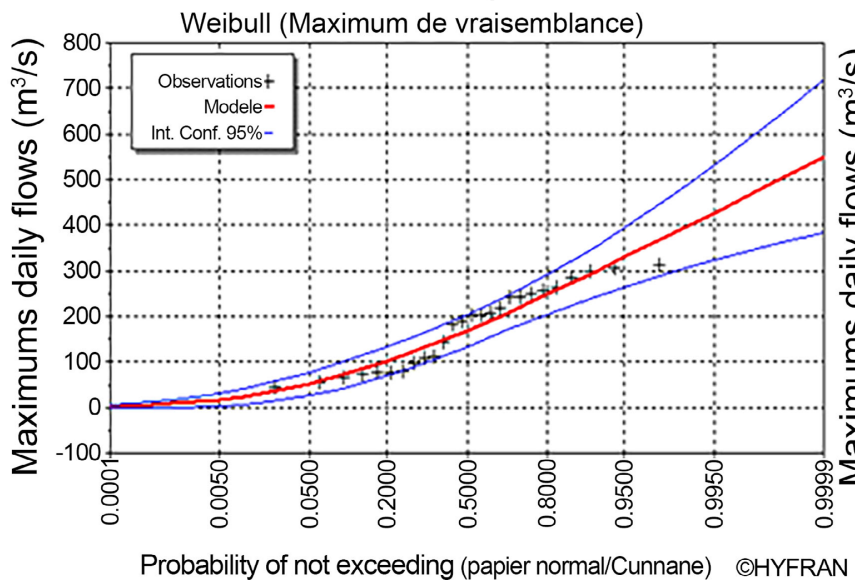

Bandama at the Korhogo-Badikaha station Gumbel (Maximum de vraisemblance)

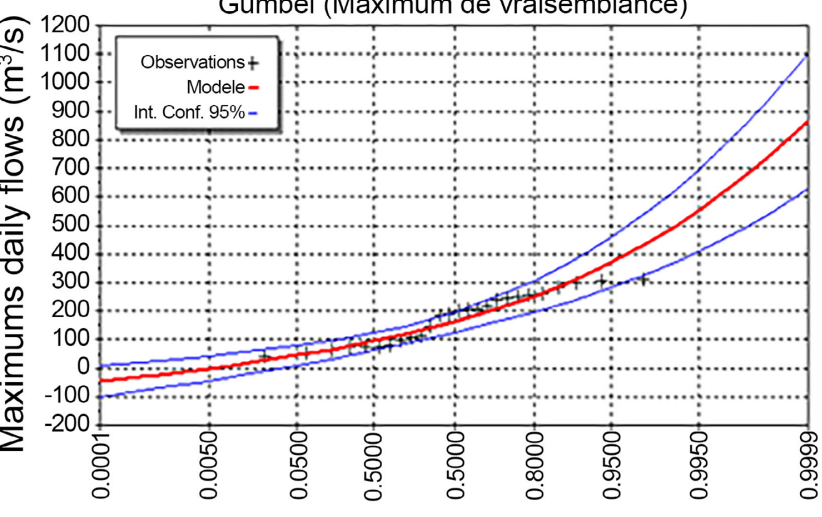

Probability of not exceeding (papier normal/Cunnane) CHYFRAN

Bandama at the Korhogo-Badikaha station Lognormale (Maximum de vraisemblance)

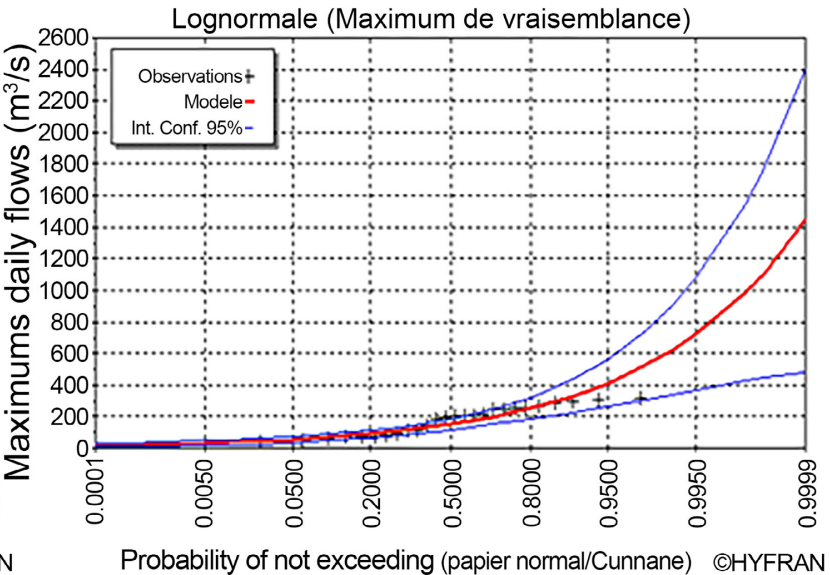

Figure 6. Graphical comparison of the adjustment of the flood series at the Korhogo Badikaha station.

Table 2. Comparison of statistical laws for the adjustment of maximum annual rainfall at the Korhogo-Badikaha road station.

\begin{tabular}{cccccc}
\hline Laws & $\begin{array}{c}\text { Number of } \\
\text { parameters }\end{array}$ & $\mathrm{P}(\mathrm{Mi} / \mathrm{x})$ & \multicolumn{2}{c}{ Comparison criterion } & \multirow{2}{*}{ Ranking } \\
\cline { 5 - 6 } & 2 & 64.37 & 310.438 & 307.922 & 1 \\
Weibull & 3 & 13.43 & 313.572 & 309.798 & 2 \\
GEV & 2 & 12.69 & 313.687 & 311.1713 & $\mathbf{3}$ \\
Gumbel & 2 & 9.51 & 314.264 & 311.748 & $\mathbf{4}$ \\
Lognormal & & & &
\end{tabular}

\subsubsection{Adjustment of Minimum Daily Flows}

At the level of the low water flows, among the competing laws, only the Gamma and Exponential laws were able to fit the observations (Figure 7). Thus, the comparison of the two laws by the BIC and AIC criteria show that the Gamma law comes first with $58.24 \%$ chance that the sample comes from this law (Table 3). The criteria of BIC (58.57) and AIC (51.06) are lower than those of the Exponential law. 

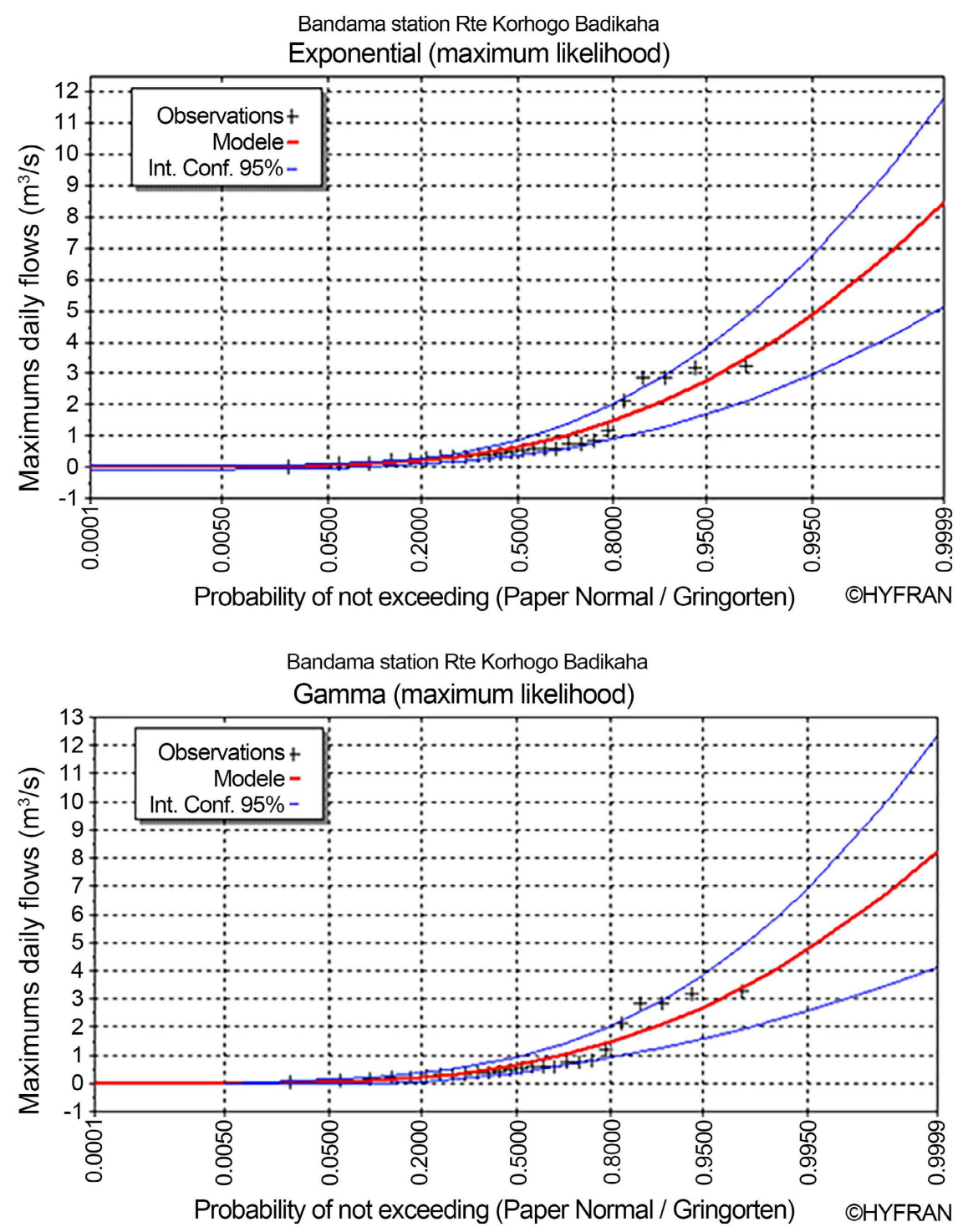

Figure 7. Graphical comparison of the adjustment of the low water series at the Korhogo Badikaha station.

Table 3. Comparison of statistical laws for the adjustment of minimum annual flows at the Korhogo-Badikaha road station.

\begin{tabular}{cccccc}
\hline \multirow{2}{*}{ Statistical law } & $\begin{array}{c}\text { Number of } \\
\text { parameters }\end{array}$ & $\mathrm{P}(\mathrm{Mi} / \mathrm{x})$ & \multicolumn{2}{c}{ Comparison criterion } & \multirow{2}{*}{ Ranking } \\
\cline { 4 - 5 } Gamma & 2 & 58.24 & 53.578 & 51.0622 & 1 \\
Exponential & 2 & 41.76 & 54.244 & 51.727 & 2 \\
\hline
\end{tabular}

\subsubsection{Flow Quantiles Analysis}

Table 4 summarizes the quantiles of minimum and maximum flows estimated according to the laws that came first in the adjustment. It can be seen that flood and low-flow rates increase with return periods. Confidence intervals are also estimated to evaluate the uncertainty associated with the estimates. 
Table 4. Quantiles of various return periods of flood and low water flows at the KorhogoBadikaha station.

\begin{tabular}{ccccc}
\hline $\begin{array}{c}\text { Return period } \\
\text { (years) }\end{array}$ & $\begin{array}{c}\text { Estimated } \\
\text { floods }\left(\mathrm{m}^{3} / \mathrm{s}\right)\end{array}$ & $\begin{array}{c}\text { Confidence } \\
\text { interval }\end{array}$ & $\begin{array}{c}\text { Estimated } \\
\text { drawdowns }\left(\mathrm{m}^{3} / \mathrm{s}\right)\end{array}$ & $\begin{array}{c}\text { Confidence } \\
\text { interval }\end{array}$ \\
\hline $\mathbf{1 0 0}$ & 401 & {$[308-494]$} & 5.27 & - \\
$\mathbf{5 0}$ & 372 & {$[291-453]$} & 4.20 & - \\
$\mathbf{2 0}$ & 330 & {$[264-395]$} & 2.94 & {$[1.24-4.64]$} \\
$\mathbf{1 0}$ & 292 & {$[238-346]$} & 2.10 & {$[1.04-3.15]$} \\
$\mathbf{5}$ & 248 & {$[204-292]$} & 1.36 & {$[0.68-2.03]$} \\
\hline
\end{tabular}

\section{Discussion}

The bathymetric study of the reservoirs used for sugarcane irrigation and the satisfaction of various water uses in the Ferkessedougou sugar complexes showed that the Morrison reservoir has a maximum depth of $11.98 \mathrm{~m}$ as of 20/02/2020. At this date, the water capacity is estimated at a volume of $11,656,735.5 \mathrm{~m}^{3}$; for the Lokpoho reservoir, the maximum depth is $8.82 \mathrm{~m}$, i.e. a volume of $4,354,531.5$ $\mathrm{m}^{3}$ at the date of 21/02/2020 Compared to the results of the work of the CCC $\mathrm{UE} / \mathrm{CI}$ in 2013, we note a difference in the maximum depths sounded and the volume of water assessed for the two reservoirs. Indeed, a maximum depth of $12.2 \mathrm{~m}$ corresponding to a water volume of $1,590,000 \mathrm{~m}^{3}$ was obtained for Morrison and while our results give a volume of $11,656,735.5 \mathrm{~m}^{3}$. It is the same for Lokpoho where a depth of $6.12 \mathrm{~m}$ or a volume of water available of $1,081,722 \mathrm{~m}^{3}$ had been found by the CCC UE/CI in 2013 (CCC UE/CI, 2013). The difference could be related to the dates of the bathymetric surveys and the water level selected for the calculations. Indeed, the bathymetric surveys were carried out in the month of February while during this period, the volumes of water withdrawn for sugarcane irrigation are less important contrary to the month of May-June (the 2013 surveys were carried out on 17/05/2013 (Lokpoho) and 06/06/2013 (Morrison)) and which is located in the major irrigation campaign where the needs of sugarcane are important which leads to a considerable decrease in the volume of water in the reservoirs.

The sediment rates obtained are $2.4 \%$ and $2.1 \%$ for Lokpoho and Morisson, respectively. These results are consistent with Tsanang (2016) who showed that the dams (Lokpoho and Morrison) lose more than $2.5 \%$ and $1.5 \%$ of their capacities every ten years, respectively, which compromises the sustainable management of these waters during the irrigation seasons. Furthermore, a comparison between the two sediment rates shows that the sediment rate for Lokpoho is higher than for Morrison. This could be explained by the presence of a high slope for Lokpoho $\left(90^{\circ}\right)$ and a low slope for Morrison $\left(24^{\circ}\right)$. It is important to remember that the siltation of the reservoirs over the years could lead to the disappearance of the water body in the years to come if nothing is done to secure the structures.

The frequency analysis of the annual maximum daily flows allowed to esti- 
mate the flood flows having a probability to occur at the Korhogo Badikaha road station. It emerges from this study that the maximum daily flows between 73.9 and $100 \mathrm{~m}^{3} / \mathrm{s}$ have the possibility of occurring every five years. Also, the decennial floods vary between 92.9 and $143 \mathrm{~m}^{3} / \mathrm{s}$ while the fiftieth floods could vary between 122 and $215 \mathrm{~m}^{3} / \mathrm{s}$. For 100-year floods, the maximum annual daily flows vary from 133 to $249 \mathrm{~m}^{3} / \mathrm{s}$. At this same station, Brida (2008) estimated the wet decennial flood at $40.2 \mathrm{~m}^{3} / \mathrm{s}$ and the dry decennial at $6.52 \mathrm{~m}^{3} / \mathrm{s}$. We note a discrepancy in the results related to the sample analyzed. Indeed, the maximum monthly annual flows represent the average of the 12 months of flows of a year. Although the mean monthly modulus is a very significant feature, its great interannual variability in tropical areas induces a great loss of information in terms of hydrological risk. The centennial minimum flow is $5.27 \mathrm{~m}^{3} / \mathrm{s}$; the fifty-year low flow is $4.20 \mathrm{~m}^{3} / \mathrm{s}$. The decadal flow could be $2.10 \mathrm{~m}^{3} / \mathrm{s}$, with a confidence interval between $1.04 \mathrm{~m}^{3} / \mathrm{s}$ and $3.15 \mathrm{~m}^{3} / \mathrm{s}$.

\section{Conclusion}

This study is being conducted to assess the current water availability of the reservoirs and to estimate the quantiles of extreme rainfall and flow and their probability of occurrence in order to provide a decision-making tool for water management in the Ferke sugar complexes.

As of 20 February 2020, the water capacity of the Morrison Dam is estimated at $11,656,735.5 \mathrm{~m}^{3}$ with a surface area of $32,000 \mathrm{~m}^{2}$. As for the Lokpoho dam, the volume of water is estimated at $4,354,531.5 \mathrm{~m}^{3}$ for a surface area of $27,000 \mathrm{~m}^{2}$. This large water capacity of the reservoirs is threatened by sedimentation. The volume of sediment in Morrison Reservoir varies from 875,900 $\mathrm{m}^{3}$ in 2013 to $1,013,058.96 \mathrm{~m}^{3}$ in 2020 , i.e. a sedimentation rate of 2.1. For the Lopkoho reservoir, the volume of sediment obtained in 2013 is $508,000 \mathrm{~m}^{3}$ and in 2020 , this volume is estimated at $599,740.54 \mathrm{~m}^{3}$, i.e. a sedimentation rate of 2.4. Major floods of the order of 73.9 and $100 \mathrm{~m}^{3} / \mathrm{s}$ could occur every five years at the Korhogo route Badikaha station. Major floods of the order of 73.9 and $100 \mathrm{~m}^{3} / \mathrm{s}$

could occur every five years at the Korhogo station, Badikaha road. During dry periods, the minimum flow that can be observed every ten years is $2.10 \mathrm{~m}^{3} / \mathrm{s}$. These results serve as an indicator for better management of water resources in the Ferkessédougou sugar complexes.

\section{Acknowledgements}

This work was carried out as part of the AFD-CLIMSUCAF project (Convention IRS/ECO/No. 499-2019). The authors would like to thank the CLIMSUCAF project and SUCAF-CI company for providing funds and data for this study.

\section{Conflicts of Interest}

The authors declare no conflicts of interest regarding the publication of this paper. 


\section{References}

Bobée, B. (1999). Estimation des événements extrêmes de crue par l'analyse fréquentielle: Une revue critique. La Houille Blanche, 85, 100-105. https://doi.org/10.1051/lhb/1999090

Brida, A. B. (2008). Elaboration de l'Atlas Hydro-Climatique de la Côte d'Ivoire: Etude statistique des écoulements de cours d'eau et bilan hydrique. Mémoire de DEA, Université Abobo-Adjamé.

Catalogne, C. (2012). Amélioration des méthodes de prédéterminations des débits de références d'étiages en des sites peu ou non jaugés. Thèse de Doctorat, Université de Grenoble.

CCC UE/CI (2013). Études APD et élaboration de DAO pour la sécurisation des ressources en eau des complexes sucriers de la Côte d'Ivoire, (Zuénoula, Ferkessédougou, Côte d'Ivoire), Cellule de Coordination de la Coopération CI/UE. Ministère de l'Agriculture de Côte d'Ivoire.

Drouin, A., \& Saint-Laurent, D. (2010). Comparaison des méthodes d'interpolation pour l'é laboration de modèles numériques d'élévation de haute précision dans la représentation micro-topographique des plaines inondables. Hydrological Sciences Journal, 55, 526-539. https://doi.org/10.1080/02626667.2010.481088

GIEC (2012). Gestion des risques de catastrophes et de phénomènes extrêmes pour les besoins de l'adaptation au changement climatique. Rapport spécial des Groupes de travail I et II du Groupe d'experts intergouvernemental sur l'évolution du climat. Cambridge University Press.

IPCC (2014). Climate Change 2014: Synthesis Report. Contribution of Working Groups I, II and III to the Fifth Assessment Report of the Intergovernmental Panel on Climate Change (pp. 1-151). IPCC.

Kouassi, A. M., Assoko, A. V. S., Kouakou, K. E., Djé, K. B., Kouamé, K. F., \& Biémi, J. (2017). Analyse des impacts hydrologiques de la variabilité climatique en Afrique de l'Ouest: Cas du bassin versant du Bandama en Côte d'Ivoire. Larhyss Journal, 31, 19-40.

Kouassi, K. M., Meledje, N. H., Koffi, Y. B., Kouassi, K. L., Ahoussi, K. E., Oga, Y. M. S., Biémi, J., \& Soro, N. (2019). Modélisation statistique des extrêmes de pluies à différentes échelles de temps: Comparaison des approches théorique et pratique. Revue Ivoirienne des Sciences et Technologies, 34, 368-388.

Kouassi, K. L. (2007). Hydrologie, transport solide et modelisation de la sedimentation dans les lacs des barrages hydroelectriques de Côte d'Ivoire: Cas du lac de Taabo. Thèse de Doctorat, Université d'Abobo-Adjamé.

Kouassi, K. L., Wognin, V. I., Gnagne, T., N'go, Y. A., Courivaud, J. R., Kassy, P., Démé, M., \& Aka, K. (2007). Caractérisation des sables et morphologie du fond du lac du barrage hydroélectrique de Taabo (Côte d'Ivoire). Sciences \& Nature, 4, 93-103. https://doi.org/10.4314/scinat.v4i1.42134

Nshimirimana, G. (2010). Caractéristiques du barrage-aménagement hydroagricole de moutori (dano) et scenarios d'utilisation de l'eau pour une irrigation efficiente et durable. Mémoire d'ingénieur. Institut International d'Ingénierie de l'Eau et Environnement.

Péné, B. C., Assa, A. B., \& Déa, G. B. (2001). Interaction eau d'irrigation-variétés de canne à sucre en conditions de rationnement hydrique. Cahiers Agricultures, 10, 243-253.

Péné, C. B., Chopart, J. L., \& Assa A. (1997). Gestion de l'irrigation à la parcelle en culture de canne à sucre (Saccharun officinarum L.) sous climat tropical humide, à travers le cas des régions Nord et Centre de la Côte d'Ivoire. Sécheresse, 8, 87-98.

Ryding, S. O., \& Rast, W. (1994). Le contrôle de l'eutrophisation des lacs et réservoirs. 
Science de l'environnement (9th ed.). Masson.

Soro, G. E. (2011). Modélisation statistique des pluies extrêmes en Côte d'Ivoire. Thèse de Doctorat, Université d'Abobo-Adjamé.

Soro, T. D., Kouakou, B. D., Kouassi, E. A., Soro, G., Kouassi, A. M., Kouadio, K. E., Yéi, M. S. O., \& Soro, N. (2013). Hydroclimatologie et dynamique de l'occupation du sol du bassin versant du Haut Bandama à Tortiya (Nord de la Côte d'Ivoire). VertigO, 13, $1-22$.

Tsanang, T. P. R. (2016). Diagnostic de système d'irrigation dans les parcelles irriguées, SUCAF-CI. Mémoire d'Ingénieur. Institut International d'Ingénierie de l'Eau et Environnement.

UNESCO, \& UN-Water (2020). The United Nations World Water Development Report 2020: Water and Climate Change. UNESCO.

Yao, A. B., Goula, B. T. A., Kouadio, Z. A., Kouakou, K. E., Kane, A., \& Sambou, S. (2012). Analyse de la variabilité climatique et quantification des ressources en eau en zone tropicale humide: Cas du bassin versant de la Lobo au Centre-Ouest de la Côte d'Ivoire. Revue Ivoirienne des Sciences et Technologies, 19, 136-157. 